Annals of Tropical Research 31[1]:1-33(2009)

(c) VSU, Leyte, Philippines

\title{
Food security implications of biofuel production
}

\author{
Teodoro C. Mendoza \\ Faculty of Crop Science, College of Agriculture, UP Los Baños, \\ College, Laguna, Philippines
}

\begin{abstract}
Producing liquid biofuel for cars to address the declining oil supply requires the same resources or inputs (land, water, initial energy or oil, fertilizer and machineries) as in producing food for humans. As early as the 1980s, all the prime lands in the world are already used for agri- and - aquaculture (1970s for the Philippines. Biofuel production consumed water (up to $10,000 \mathrm{~L}$ of water $/ \mathrm{L}$ ethanol). At present, $74 \%$ of water is used to irrigate food crops. Only $1 \%$ water is now used for biofuel but this water consumption will increase to $80 \%$ if the biofuel production plan materializes. One out of three individuals in the world is now suffering from water scarcity. Global warming/global climate change, droughts, more forest fires and high evaporation triggered by high temperature will further magnify the diminishing supply of fresh water both for agriculture and domestic use (household and industries).
\end{abstract}

The simple linear thought is.....more crops for food or biofuel = more lands and water use $=$ more fertilizer or oil use $=$ more erosion $=$ more greenhouse gas emission.

Biofuels have forced global food prices up by $75 \%$, a World Bank study showed. In 2007, 100 metric tons (Mt) of grains were processed into biofuel . This precipitated to food price spikes in the following year. It is clear that without biofuel in the food equation, there will be enough food. As more money is spent for food, food price spikes have caused 100 million people to be below poverty line and food riots in 36 countries. About 3 billion people are now affected especially those who spend 60$70 \%$ of their income on food. There aremany options other than biofuel such as solar, wind, and wave. The technology is now in place for solar- powered and battery/electric or hybrid cars for transport. In the Philippines (a tropical country), geothermal, hydroelectric, wind and solar power, are so abundant. They remain to be tapped.

Correspondence: T. C. Mendoza Address: Faculty of Crop Science, College of Agriculture, UP Los Baños, College, Laguna, Philippines.Email: tcm_uplb77@yahoo.com.

Dol: $10.32945 /$ atr3111.2009 
Keywords: Food security, biofuel, ethanol, biodiesel, distillery slop, biodiversity, erosion, greenhouse gas, global warming/climate change, food miles, globalization, cheap food, cheap oil

Abbreviations: GWP-global warming potential, Mt- million tons, Mha- million hectares, GHG-green house gas, NOx-nitrogen oxides, CPI-consumer price index, FAO-Food \&Agriculture Organization, CIA-Central Intelligence Agency

\section{BRIEF BACKGROUND}

Considering food production and consumption, the current food crisis is no surprise. On the production side, food production is carried out under an increasingly difficult production environment -global warming /global climate change - floods, typhoon, droughts, narrowing cycles of El Niño/La Niña, reduced R \& D for agriculture, the continuing increase of oil price which propelled a price leap of oil-based inputs (fertilizer \& pesticides ), decreasing production capacity of the agroecosystem to meet requirements or the deteriorating resource base for production (Fig.1).

Human beings directly manage $27 \%$ of the Earth's surface area and harvest more than $40 \%$ of the planet's biological productivity (Vitousek et al., 1986 ; Cox et al.,2002;2006). Yet food production per person is on the decline, and agriculture worldwide is worsening the global ecological crisis (Tillman et al., 2001; Vidal,2007; Magdoff, 2008 ; Cox, 2008).The arable surface of the Earth (1.4 billion ha) is now fully utilized by agriculture and aquaculture (Buringh, 1989 ; Kindell and Pimentel, 1994). In the Philippines, as early as the 1970s, all the prime agricultural lands (10 million ha) (Mendoza, 2008) have already been cultivated. Expansion will encroach on fragile and less favorable agro-environments which are too steep, too dry, or with barren soils (Buringh, 1989). Of the 1.4

\footnotetext{
*Paper presented during the $30^{\text {th }}$ Annual Scientific Meeting of the NATIONALACADEMY OF SCIENCE AND TECHNOLOGY, PHILIPPINES; Plenary Session III on Energy and Food , held on 10 July,2008 at the Manila Hotel, Metro Manila, Philippines.
} 


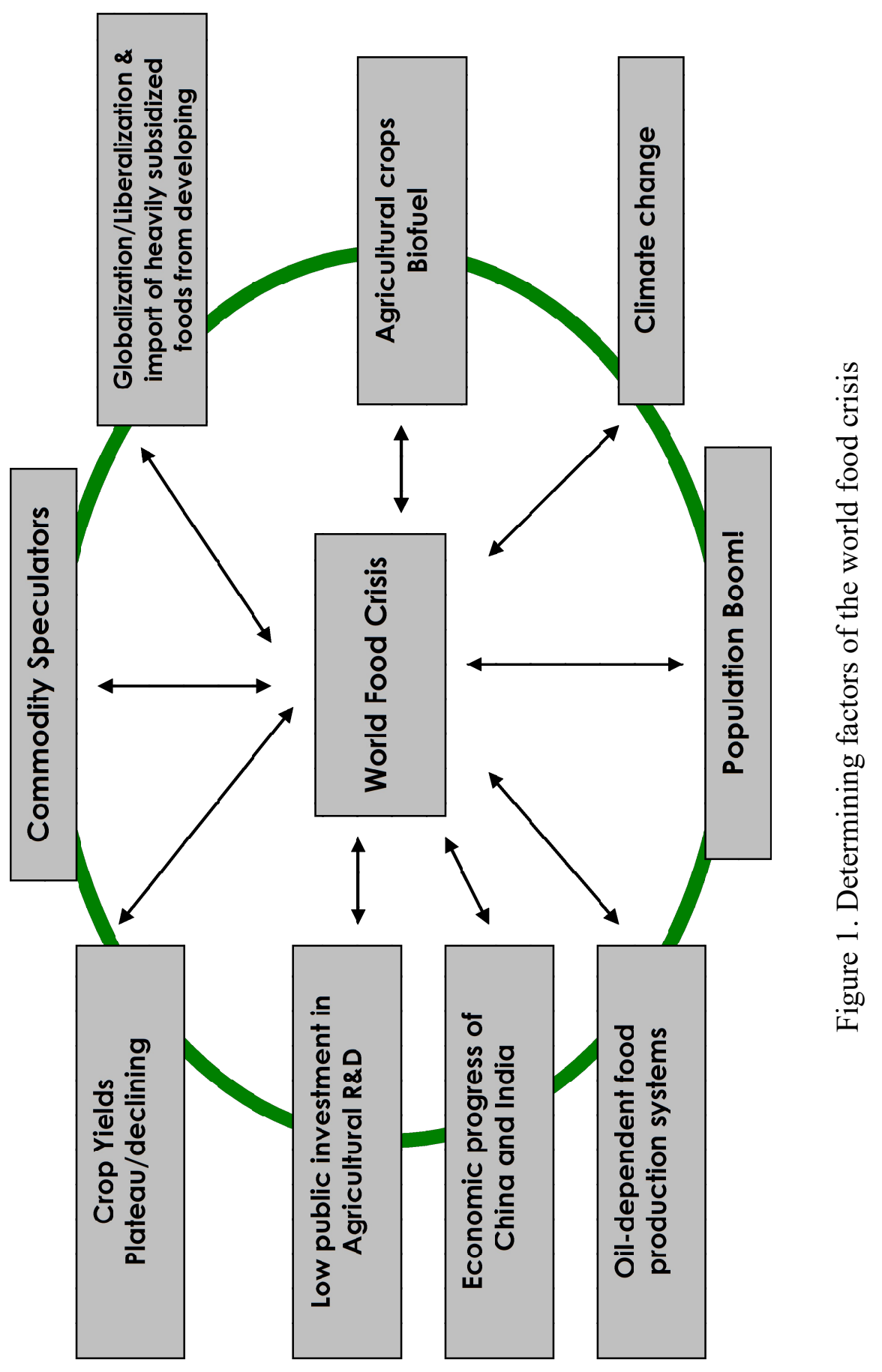


billion ha cultivated lands, about 327 million ha or $34 \%$ have been degraded. An average of 9 million ha are eroded every year and soils are being destroyed 13 times faster than the natural soil formation. Some 400 million ha irrigated lands or $30 \%$ are desertified by salinization. With these diminishing lands for food production, "How Many People Could the Earth Support?" Ross McCluney ( http://www.ecofuture.org/pop/rpts/ mccluney_maxpop.html) revealed a wide range of values from only 2 billion (Pimentel estimates) to as high as 40 billion by eating a vegetarian diet (at 2,500 kcal, Revelle, 1976 as cited by Cohen, 1995). In the Philippines, the estimated ideal agricultural area is $0.43 \mathrm{ha} /$ person. This translates to about 28 million Filipinos who could be ideally living in the country ( the Philippine population in 1960s). It means, we have exceeded our ideal population three times! The babies who will be born in the next 15 years will need another Philippines (Mendoza, 2008).

On the consumption side, the huge population especially among poor and food-deficient countries, the increasing affluence of fast-growing economies particularly China and India comprise about $40 \%$ of world population, is leading to greater consumption of oil and meat or animal products. All together, the demand for food increased. The current trade regime or globalization has brought about the interconnected adverse effects not only on the environment (Altieri \& Bravo, 2007; Magdoff, 2008) but also on energy use (by increased food miles, McKei, 2008; Defra, 2005) and food insecurity especially in the poorer countries. Heavily subsidized agricultural products of developed countries and exported cheap to developing countries, like the Philippines, led to the belief that it is more practical to import food (which also increased food miles, McKei, 2008). Why produce when it is cheaper to import? But this was short-lived as food prices in the world market had increased.

\section{The food supply status}

Reserves of cereals (FAO, 2008) revealed that world wheat declined $11 \%$ in 2007 , the lowest level of food reserves since 1980 as it is only good for 12 weeks of the world's total consumption - $22 \%$ less than the average 18 weeks food stored in 2000-2005. In Australia, wheat 
production decreased by 50\% since the 2005-06 crop year because of drought while Canadian wheat fell $20.6 \%$ in 2007 and their exports fell by 6 million tons (Mt). US, Australia and Canada are the tiop 3 exporters of cereals in the world. Rice yields came to a plateau or yield increases are so minimal. Rice production increased at $2.5-3.0 \%$ per year in the $1970 \mathrm{~s}$ and 1980s. In the 1990s onward, the growth rate was only1.5\% (Cassman ,1999 as cited by Mendoza, 2008).Global stockpiles of cereals is estimated to decline by $53 \mathrm{mt}$ this year (Elisabeth Rosenthal: http:// www.iht.com/articles/2007/12/17/europe/food.php).

In the Philippines, in particular, enough rice is guranteed through rice import at 2.7 million metric tons for buffer stock, the Government claimed and this year 2008, the first harvest of the year was $7.1 \mathrm{Mt}(41 \%)$ (Dept. of Agric., Philippine Daily Inquirer (PDI), June 25, 2008).The expected harvest of about $10.22 \mathrm{Mt}(59 \%)$ for the rest of the year could not be achieved and so with the expected harvest for the year (17. 32 $\mathrm{Mt}$ ).Altogether, this was attributed to typhoons, floods and lower applications of fertilizer input by the farmers which in turn is due to its high price .Our rice supply may not be that critical this year but increasing population and the other yield depressing factors cited above may put our food security in great peril starting 2015 (or even much earlier ) when our rice demand will increase by $20 \%$ relative to our 2008 consumption ( Table 1).

\section{Food price crisis or simple human denials?}

The era of cheap food is over, the chief of the Asian Development Bank Chief said. The UN's food price index rose 45 percent in the past 10 months but some prices have climbed even faster. Wheat went up $108 \%$ in the past 12 months; corn, $66 \%$ and rice $220 \%$, (2007 to date), the food that feeds half of the world, went "from being a staple to a delicacy," (Ofon,2008)http://www.theglobeandmail.com/servlet /story/RTGAM.20080410.wfood0411/BNStory/International/home ). Poor people are simply priced out! In 2007, commercial rice can be bought as low as Php17.50/kg. As of this date (October 2008), rice is sold at 


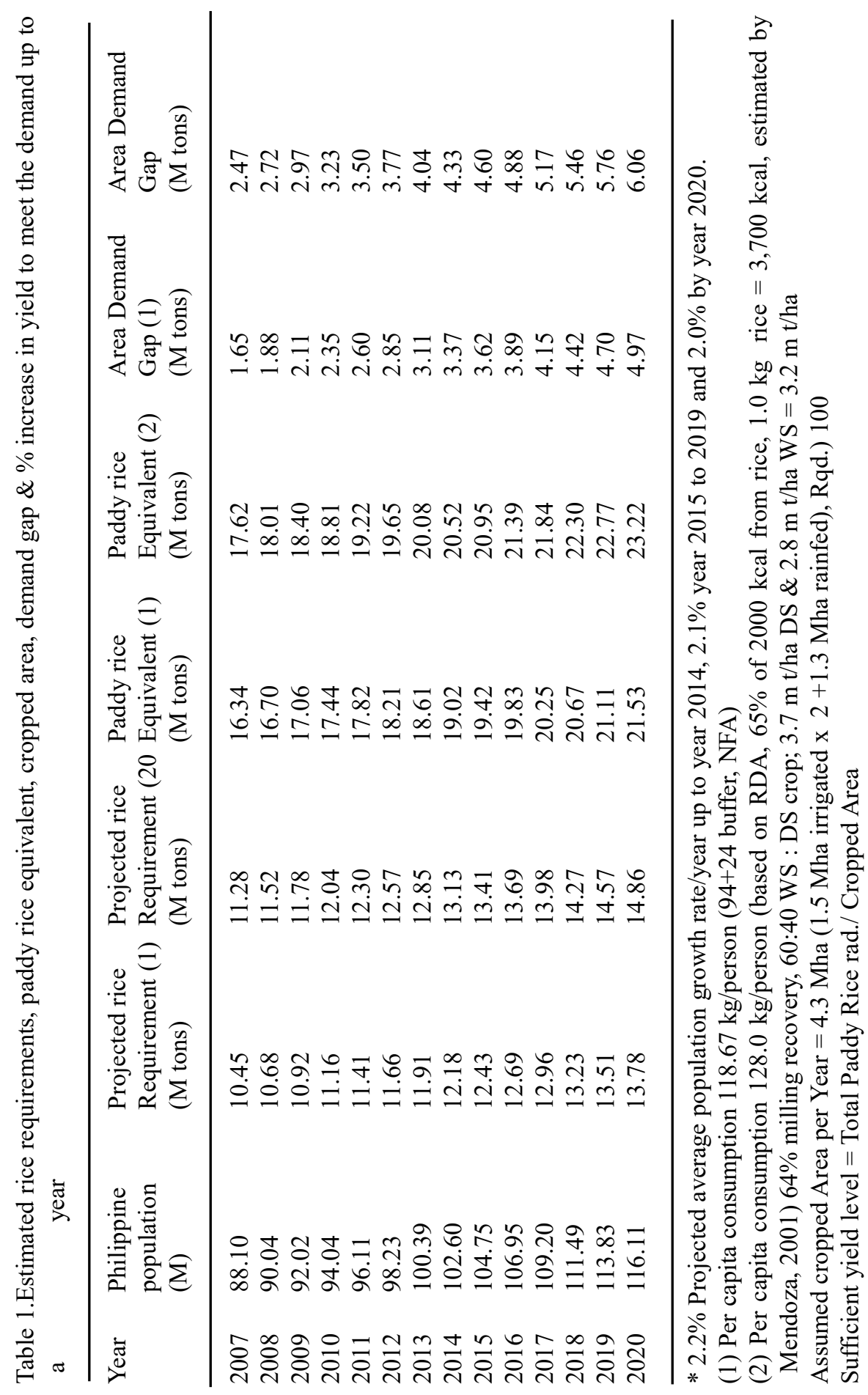


Table 2. Estimated farm gate price of paddy rice and equivalent retail price per $\mathrm{kg}$ at various imported price (in US D/metric ton)

\begin{tabular}{lll}
\hline $\begin{array}{l}\text { Imported price } \\
\text { of rice (1) } \\
\text { (USD/ton) }\end{array}$ & $\begin{array}{l}\text { Farm gate price of } \\
\text { palay } / \mathrm{kg}(2) \\
(\mathrm{Php} / \mathrm{kg})\end{array}$ & $\begin{array}{l}\text { Retail price per kg (3) } \\
(\mathrm{Php} / \mathrm{kg})\end{array}$ \\
\hline 700 & 19.50 & 40.60 \\
800 & 22.74 & 46.40 \\
900 & 25.06 & 52.20 \\
1200 & 33.41 & 69.60 \\
1300 & 36.20 & 75.40 \\
1400 & 38.98 & 81.20 \\
1500 & 41.76 & 87.00 \\
1600 & 44.54 & 92.80 \\
1700 & 47.33 & 98.60 \\
1800 & 50.18 & 104.20 \\
1900 & 52.90 & 110.20 \\
2000 & 55.68 & 116.00 \\
\hline
\end{tabular}

Notes:

1) Imported price at USD/metric ton, $\$ 1=\mathrm{P} 43$ exchange rate, no tariff. Shipping costs are included.

2) The farm gate price of palay is estimated directly from the imported price plus costs of handling (Nueva Ecija is the reference pt.)

3) Teh retail price per $\mathrm{kg}$ is estimated at zero tarrif, $\$ 1=\mathrm{P} 43$ exchange rate, plus handling

costs (Nueva Ecija is the reference pt.), $64 \%$ miling recovery.

$\mathrm{P} 40 / \mathrm{kg}$ and the cheapest is $\mathrm{P} 26 / \mathrm{kg}$ which is $48.6 \%$ more expensive than it was a year ago. Is it really expensive? Is this the true market price of rice in the Philippines? How much is the true price of rice? Prices were determined in three different ways (Mendoza, 2008) and the estimated prices were as follows: Imported rice ( at $\$ 1136 / \mathrm{t})=\mathrm{P} 66 / \mathrm{kg}$ (Table 2), CPI corrected $(1975$ to 2008$)=\mathrm{P} 68 / \mathrm{kg}$ (Table 3$)$, and adjusted price of rice with oil price at $\$ 100 /$ barrel $=\mathrm{P} 70 / \mathrm{kg}$ (Table 4)

If the price of rice was $\mathrm{Php} 2.50 / \mathrm{kg}$ in 1975 and it is indexed to 2008, it should fetch Php 68.48/kg (Table 3 ). The 2008 rice price spike (P50/kg in Davao) was not a spike after all but reflective only of the true market price of rice in the domestic market (Mendoza, 2008). In the Philippines, the price of basic food is not allowed to freely move up or 
Table 3. Consumer price index (CPI) for selected commodities used to adjust the price of rice (1973 base year)

\begin{tabular}{lcccl}
\hline A & B & C & D & E \\
\hline Year & FBT & $1978=100$ & $1973=100$ & \\
1973 & 55.40 & 55.40 & 100.00 & 1.00 \\
1978 & 100.00 & 100.00 & 180.51 & 1.81 \\
1988 & 380.40 & 380.40 & 686.64 & 6.87 \\
1990 & 429.50 & & & \\
1988 & 100.00 & 380.40 & 686.64 & 6.87 \\
1992 & 157.30 & & & \\
1994 & 180.70 & 687.38 & $1,240.76$ & 12.41 \\
1996 & 217.40 & & & \\
1994 & 100.00 & 687.38 & $1,240.76$ & 12.41 \\
2000 & 145.50 & $1,000.14$ & $1,805.31$ & 18.05 \\
1992 & 66.10 & & & \\
1996 & 84.30 & & & \\
2000 & 100.00 & $1,000.14$ & $1,805.31$ & 18.05 \\
2007 & 134.90 & $1,349.19$ & $2,435.36$ & 24.35 \\
$2008 *$ May & 151.60 & $1,516.22$ & $2,736.85$ & 27.37 \\
\hline
\end{tabular}

* (http://www.census.gov.ph/data/sectordata/2008/cp080501r.htm)

$\mathrm{A}=$ Representative years.

$\mathrm{B}=$ CPIs for Food, Beverages \& Tobacco Philippine Statistics Yearbooks (1987 2007).

$\mathrm{C}=$ Adjusted CPI consistent with 1978 base price $(1978=100)$.

$\mathrm{D}=$ adjusted CPI using data in C to make 1993 the base year.

$\mathrm{E}=\mathrm{CPI}$ as price ratio at 1973 base year. 2008 Adjusted price of rice (1973 base year)

$$
\begin{gathered}
= \\
27.36 \times 2.5=\mathrm{P} 68.40 / \mathrm{kg}
\end{gathered}
$$

down based on the market forces. It is the policy of the state to make food available and affordable (food security) through direct and indirect interventions. In the case of rice, the National Food Authority (NFA) always ensures that enough supply is available (achieved mainly through importation) so that rice prices in the domestic market is stabilized. Viewed from the perspective of the low wage earners, this strategy of the government is highly laudable. If the government cannot force employers to increase wages, it can at least maintain food prices at 
Table 4 . Estimated rice price adjustments as the price of oil increases

\begin{tabular}{llccc}
\hline \multirow{2}{*}{$\begin{array}{l}\text { Oil Price } \\
\text { Per Barrel } \\
\text { (US\$) }\end{array}$} & $\begin{array}{l}\text { Price Of Urea } \\
\text { Per Bag }\end{array}$ & \multicolumn{3}{c}{ Price of Palay/Rice } \\
& $(50 \mathrm{~kg})$ & 1 & 2 & 3 \\
\hline 100 & 1050 & 1050 & 21.0 & 57.00 \\
110 & 1230 & 1230 & 24.6 & 70.62 \\
120 & 1410 & 1410 & 28.2 & 78.54 \\
130 & 1590 & 1590 & 31.8 & 86.46 \\
140 & 1770 & 1770 & 35.4 & 94.38 \\
150 & 1950 & 1950 & 39.0 & 102.30 \\
\hline
\end{tabular}

1- Price of Urea = Price of Palay. 2- Farm gate price of palay = palay price per cavan $/ 50 \mathrm{~kg}$. 3Price of rice $($ retail $)=2 \mathrm{x}$ price of palay $/ \mathrm{kg}+$ post-production costs. Post-production $=$ Drying hauling, milling, warehousing, sack, profit (approximately P15/kg) Source :Mendoza 2008)

affordable levels. But this is disincentive to the farmers because they could hardly make a living out of farming. Subsidizing rice, a form of cash transfer to the poor, will mean huge costs. It was estimated that the National Food Authority had incurred losses up to P37 billion in 2007 (PDI, June 13, 2007). Rice farming is associated to poverty. It is no surprise that poverty is a rural phenomenon in the Philippines since 9 out of 10 farmers are rice farmers (Mendoza, 2001).

\section{Oil dependent food systems}

Humanity is overconsuming oil. Over 1.5 trillion barrels of oil equivalent had been consumed since Edwin Drake drilled the first oil well in 1859 (www.energyandcapital.com) and in 40 years, the remaining 1.5 trillon will be consumed at the current rate of utilization of 85 million barrels a day, or about 31 billion barrels/year (BP Global Statistical Review of World Energy, 2007 ). What Earth stored in 9 million years (Rodolfo, 2008), humanity consumes in one year. The era of cheap oil is gone! Oil price increasing to an unaffordable level also has positive effect as it will accelerate the shift to alternative energy sources and it will decrease considerably oil consumption. This in turn will reduce significantly greenhouse gas emission, thus, saving humanity by not reaching the predicted tipping point of 2 degrees centigrade increase in 
temperature (Hansen, 2003).

Why is oil so important in our food systems? Simple! Our food systems use so much oil to cultivate, fertilize, harvest, process, store, and distribute food. From production - to- post production, rice utilizes an oil equivalent of $830 \mathrm{li}$ or $42 \mathrm{~L}$ oil at $128 \mathrm{~kg} /$ rice per person. Sugarcane uses $1120 \mathrm{~L}$ oil equivalent or $2.4 \mathrm{~L}$ oil at $20 \mathrm{~kg}$ sugar/capita (Mendoza, 2008). Prices of food are inevitably affected with oil price increases. As the era of cheap oil is gone, so with the era of cheap food in view of the excessive dependence of our food systems on oil. In the United States, 1514 li of oil equivalents are expended annually to feed each American (Pfeiffer, 2003). Agricultural energy consumption is broken down as follows: $31 \%$ for the manufacture of inorganic fertilizer, $9 \%$ for the operation of field machinery, $16 \%$ for transportation, $13 \%$ for irrigation, $8 \%$ for raising livestock (not including livestock feed), $5 \%$ for crop drying, $5 \%$ for pesticide production, $8 \%$ miscellaneous (Pimentel and Giampietro, 1994 ; McLaughlin et al., 2000 as cited by Pfeiffer, 2003). The first International Agriculture Assessment on Science and Technology Development (IAASTD, 2008) approved by 54 governments scored industrial agriculture as a causal factor in increasing food prices, hunger, social inequities, and environmental disasters (http://www.agassessmentwatch.organdhttp://www.panna.org/).

\section{The biofuel option}

The over utilization of oil has brought about complex situations. The fast dwindling supply and the ensuing oil price spikes led to a breathtaking speed of biofuel production. Harrabin (2008) had called for a delay in biofuel production until proper safeguards and policies are crafted. Food crops (corn, soybean etc.) being processed into biofuel increased the demand of crops used as feedstocks which intensely compete with the same resources - land, water, financial \& human capitalbeing used for food production. The current thinking is that biofuel production is good for our economy as summarized in Fig.2. 


\section{Biofuels..........}
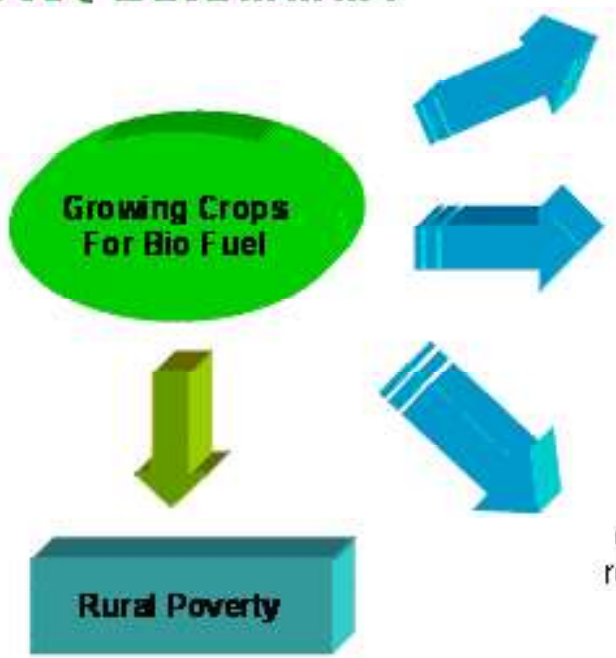

Generate Rural and Urban

Employment

More Stable but Higher Pric es

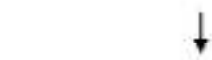

Higher Income for $F$ armers

Propel Rural Development

(Construction of Infrastructures like roads, bridges, and electric facilities)

Figure 2. Perceived benefits of biofuel production. 
Let us assess biofuels if they are really advantageous .

Biofuels and net energy yields

There are 2 considerations: (1) Crops as Feedstocks- For bioethanol --- sugarcane, corn, sorghum, root crops; For biodiesel--- palm oil, soybean, rapeseed, canola, castor oil, Jatropha, and (2) Net Energy yields from a given crop source. Net Energy Yield = Gross Energy yield less Cost of Energy. This can be simply derived by estimating the Energy Efficiency $(\mathrm{Ee})=$ Energy Output /Energy Input ( Energy Balance ). Others defined this as EROI ( Energy Returned/ Energy Input) (Cleveland et al.,1999; EROEI.com the_chain/what_is_ero

$$
\operatorname{EROI}_{t}^{*}=\frac{\sum_{i=1}^{n} \lambda_{i, t} E_{i, t}^{\mathrm{o}}}{\sum_{i=1}^{n} \lambda_{i, t} E_{i, t}^{\mathrm{c}}}
$$

? eroei.com/articles/

where $\hat{\lambda}_{i, t}$ is the quality factor for fuel type $i$ at time $t$ and Eo and Ec are the thermal equivalents of energy outputs and energy inputs, respectively.

The other is Energy Intensity (Ei) or the amount of energy used to produce $1.0 \mathrm{li}$ of energy (ethanol) or $\mathrm{Ei}=1 / \mathrm{Ee}$ (Mendoza, 2008). As shown on Table 5, only 1 crop-sugarcane - is showing a positive energy balance. While sugarcane showed $\mathrm{Ee}=2.8-3.05$, the optimum energy efficiency as estimated by Hall (2003) is $\mathrm{Ee}=5$. The energy balance of ethanol production from sugarcane in Brazil $\mathrm{Ee}=8$ (Macedo et al.,2004). In Table 6, the energy accounting for Jatropha, the most popular crop for biodiesel as it is not edible and it is known to grow in marginal soils, showed a dismal note. The energy balance ranges from 0.53 to 1.03 , for low and high yield, respectively, at the field level production stage. It 
Food security implications of biofuel production

Table 5. Energy efficiency (Ee) and energy intensity (Ei) of the various feedstock sources for ethanol production (Source: Mendoza,2008).

\begin{tabular}{|c|c|c|c|c|}
\hline \multirow[t]{2}{*}{ Feedstock } & & Yield Level Energy & Energy & Reference \\
\hline & \multicolumn{2}{|r|}{ Efficiency } & \multicolumn{2}{|l|}{ Intensity* } \\
\hline \multirow[t]{2}{*}{ Sugarcane $^{2}$} & Average & 2.80 & 0.357 & Mendoza et al 2007 \\
\hline & High & 3.05 & 0.327 & Mendoza et al 2007 \\
\hline \multirow[t]{3}{*}{ Corn $^{3}$} & Low & 1.06 & 0.940 & Moriss 1994 \\
\hline & Average & 1.25 & .800 & Shappouri et al 1995 \\
\hline & High & 1.38 & 0.724 & Lorenz \& Moriss, 1995 \\
\hline \multirow[t]{2}{*}{ Cassava $^{4}$} & Average & 1.00 & 1.000 & Hill et al 2006 \\
\hline & High & 1.32 & 0.757 & Hill et al 2006 \\
\hline \multirow[t]{2}{*}{ Sweet Sorghum } & Average & 0.91 & 1.090 & Worley et al 1992 \\
\hline & High & 1.09 & 0.910 & Worley et al 1992 \\
\hline
\end{tabular}

means that the energy consumed in processing are not yet included (Ratilla \& Mendoza, 2008).

\section{Biofuels and energy supply}

The US government study showed that by 2030, all renewable energy including biofuels will only supply $9 \%$ of global energy needs. If divided equally among the 4 main sources, biofuel will only provide $2.25 \%$ of the energy supply. The entire US corn harvest will only provide $12 \%$ of their gasoline needs and their entire soybean harvest, only $6 \%$ of their diesel fuel requirements. In Europe, $60 \%$ of their arable lands could only replace $20 \%$ of the fossil fuels used in transport. A $5.75 \%$ target would require $1 / 4$ of the EU's arable land (Goldman, 2006). In the Philippines, if all the sugarcane planted in the 390,000 ha are harvested \& fermented into ethanol, it will only provide $7.3 \%$ of our gasoline requirements and sugarcane must be planted in 5.2 million ha to satisfy $100 \%$ of the country's gas requirements by 2011 . The $10 \%$ ethanol mix with gasoline needs 200,000 ha of new sugarlands (Mendoza et al.,2007). All over the world, biofuels production shall use lands over and above the existing lands for food crops as follows: Brazil....120 Mha, Africa.....400Mha , Indonesia...20 to 30Mha and in USA... all their corn lands and $14 \%$ more...Approximately, the new land requirements for biofuels would be 564 Mha (Mendoza, 2008). Where shall we get all 


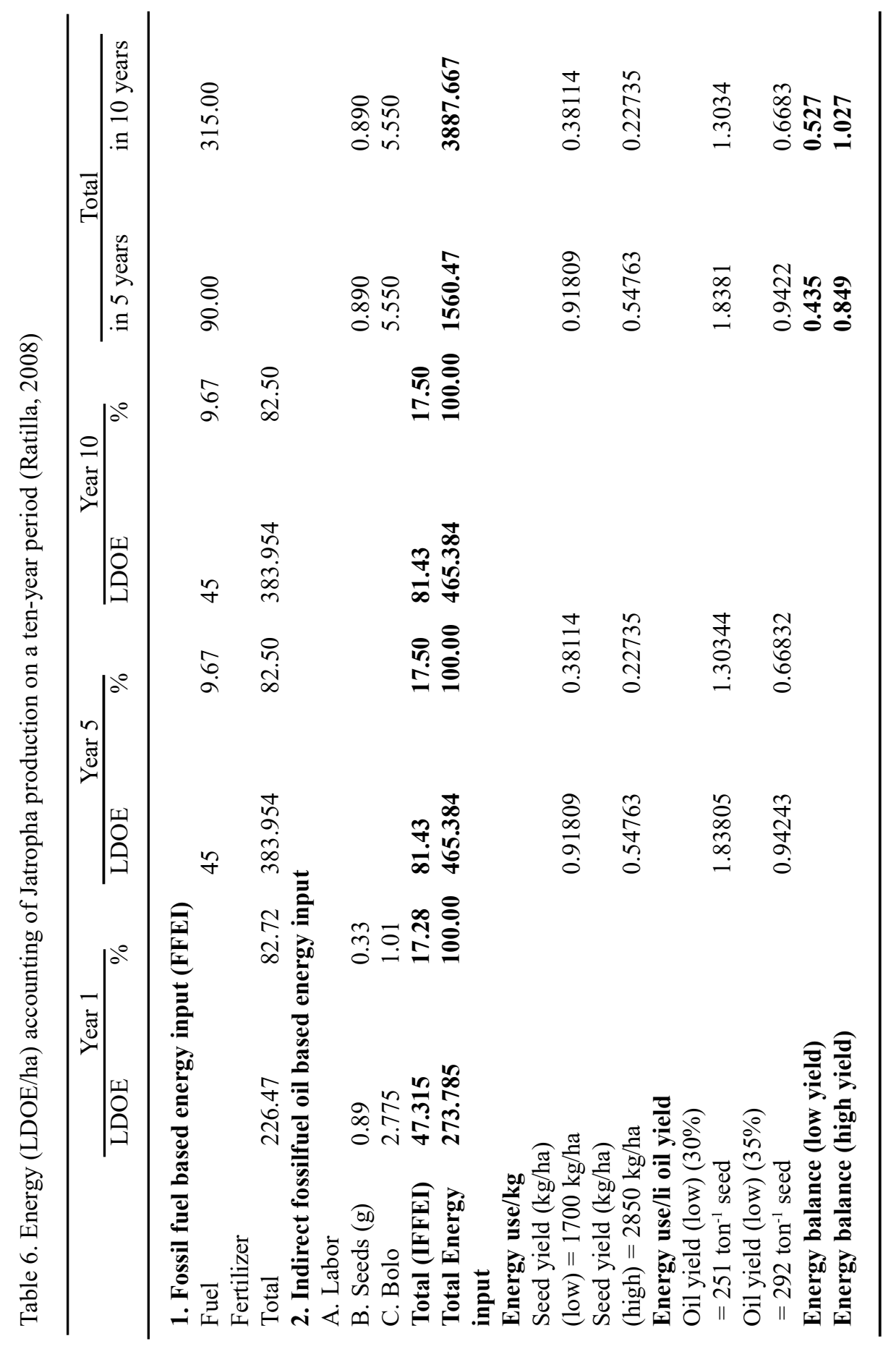


Table 7. Water consumed per liter ethanol produced*

\begin{tabular}{ll}
\hline Feedstock & \multicolumn{1}{c}{ Liter Water Use/Liter of Ethanol++ } \\
\hline Sugarcane & $3,000-4,200$ \\
Corn & $3,670-6,080$ \\
Cassava & $3,000-9,700$ \\
Sweet sorghum & $3,100-5,200$ \\
\hline
\end{tabular}

these lands without affecting food supply? About the same land area should be cultivated to provide the food requirements of the increasing population by 2030 at the current productivity levels.

\section{Biofuel and water}

About 2,000-10,000 $\mathrm{L}$ of water is needed to produce a $\mathrm{L}$ of biofuel. In Brazil, they use 2,200 L of water/ $1 \mathrm{~L}$ of ethanol from sugarcane, Phil $=3,000-4,200$, India $=3,500 \mathrm{~L} .1 \mathrm{~L}$ corn ethanol consumes 4,00010,000 li of water in the US. Table 7 shows the water bill for ethanol production for various crops in the Philippines (Mendoza,2008). The International Water Management Institute (IWMI) 5 year study on global water scenario showed that biofuel crops currently consume just 1 percent of the total water used globally .If biofuel usage rises as projected, it would be using 80 per cent more water by 2030 . Currently, $74 \%$ of all water is used for irrigation. There shall be 3 billion extra people by 2050 and this will result in an 80 percent increase in water use for agriculture". "If people are growing biofuels and food at the same time, more water will be needed!" Where shall we get all the water we need ?, David Molden asked (Sri Lanka-based IWMI). Production of biofuels could worsen water shortages (Alister, 2006. http://today.reuters.com/News/ CrisesArticle.aspx?storyId=L18850725 8/24/2006 ). At present,"One in three people in the world is enduring in one form or another, water scarcity".

\section{Biofuel and the environment}

That biofuels are renewable and environment-friendly and they can help reduce global warming are the common perception. There are 2 
main points for biofuels:(1) They are 'carbon-neutral.' When burned, the $\mathrm{CO}_{2}$ released is re-absorbed by the crops for photosynthesis - so there is no net increase in $\mathrm{CO}_{2}$; (2) Biofuels are renewable energy sources with a 1 -year cycling time, while fossil fuel oils take several million years to be formed (Rodolfo, 2008; Magdoff, 2008). On the other hand, producing biofuel shows the following negative environmental features: In Brazil, more sugarcane and soybean for biofuel are grown by burning and clearing large forested areas of the Amazon jungle. Tropical forests cleared for sugarcane ethanol emit 50\% more greenhouse gases than the production and use of the same amount of gasoline (Hill et al., 2006). More oil palms are planted in Indonesia by clearing the forest and drying/ burning their peat soils, making it the 3rd highest emitter of greenhouse gases (GHG). Every ton of palm oil produced results in 33 tons of carbon dioxide emissions-10 times more than petroleum (Monbiot, 2007). As revealed by Friends of the Earth, production of palm oil is the biggest cause of rainforest devastation. Massive production of biofuels in these areas will reduce the carbon content of soils and carbon stocks in forests and peat lands (UN-Energy 2007). Doug Parr, chief British scientist at Greenpeace, says 'producing 5\% of biofuels may end up wiping out our existing ancient forests and all the carbon gains are lost' (Holt-Gimenez 2007).

Growing crops for biofuel now is following the industrial plantation agricultural technology. Industrial agriculture is so oil energy-intensive that it contributes an enormous amount of greenhouse gases. For instance, ethanol production from corn uses oil at every stage. The largest source of green house gases are the chemical fertilizers (nitrogen is often the limiting factor in crop production). First, a huge amount of oil is consumed in the manufacture of nitrogen fertilizer. Including transport and storage, the energy use ranges from 1.8-2.04 L of oil per kg nitrogen(2.15 LDOE/ $\mathrm{kg}$ once nitrogen fertilizer reaches the fields in the Philippines, Mendoza, 2008). 'Fertilizer energy' is $28 \%$ of the energy used in agriculture (Heller and Keoleian, 2003). Second, once applied in the soil, 3-5\% of it escapes as [nitrogen oxides] NOx. NOx has 296x global warming potential (GWP). For every $1 \mathrm{~kg}$ nitrogen, more than $12 \mathrm{~kg} \mathrm{CO}$ equivalent is emitted in the atmosphere. Above all, growing maize erodes soils, pollutes 
both surface and ground waters from fertilizer run-off and deep percolation. Also, industrial plantation thrives on large scale monocropping leading to significant biodiversity loss, soil erosion and nutrient leaching (UN-Energy, 2007). Because of these, more hydrocarbon-based fertilizers must be applied to offset soil fertility decline, along with more pesticides application; more irrigation water, requiring more energy to pump; and more fossil fuels to process polluted waters (Pfeiffer, 2003). Loss of topsoil has been a major factor in the fall of civilizations (Carter and Dale, 1981). Iraq, formerly Mesopotamia, is where $75 \%$ of the farm land has become a salty desert. It takes 500 years to replace 1 inch of topsoil. In soil made susceptible by agriculture, erosion is reducing productivity up to $65 \%$ each year. The soil is eroding 30 times faster than the natural formation rate (Pimentel et al.,1995). Biofuel production from corn (i.e., butanol, ethanol) is especially harmful because corn causes 50 times more soil erosion than hay crops (Sullivan, 2004). The US government has studied the effect of growing continuous corn and found it increases eutrophication by $189 \%$, global warming by $71 \%$, and acidification by $6 \%$ (Pimentel et al.,2005). The greenhouse gas contribution of agriculture and land use change has been summed up to $32 \%$ (IPCC, 2006). Primary agriculture contributes $14 \%$, land use change/deforestation, $18 \%$. As more biofuel crops will be grown, large land clearings/deforestation will be done. About 564M ha will be needed to grow biofuel crops. This huge land requirements will inevitably lead to more deforestation, further reducing biodiversity, decreasing water supply and water quality, and increasing further soil erosion (Tegtmeier, 2004). Orangutans, rhinos, tigers and thousands of other species may be driven extinct (Monbiot, 2005). In turn, this will lead to more GHG emission. The FAO World Food Summit (2006) Report revealed that conventional agriculture, together with deforestation and rangeland burning, are responsible for $30 \% \mathrm{CO}_{2}$ and $90 \%$ of nitrous oxide emissions worldwide. The Amazon is being destroyed by farmers growing soybeans for food and fuel (Olmstead, 2006 ).

To reduce the cost of processing, coal is used in ethanol production, replacing petroleum (Farrell, 2006; Yacobucci, 2006). Using coal for burning/heating biomass factories increases global warming (Farrell, 
2006).

Many people believe that sourcing biofuel from human inedible crop sources like cellulosic biomass will correct its ugly features. But biofuels from biomass are also not sustainable, are ecologically destructive (Tegtmeier, 2004), have a net energy loss, and there are insufficient biomass to make significant amounts of energy because essential inputs like water, land, fossil fuels, and phosphate ores are limited. Biomass yields will also decline when residues are removed from the soil (Johnson, 2006). Farmers will not sell their residues as prices of fertilizers rise due to oil and natural gas depletion. It will be cheaper to return residues to the soil than to buy fertilizer. Fertile soil will be destroyed if crops and other 'wastes'are removed to make cellulosic ethanol (Andrews, 2006; Blanco-Canqui et al. , 2006). Removing crop residues would rob organic matter that is vital to the maintenance of soil fertility and tilth, leading to disastrous soil erosion levels (Magdoff and Weil, 2004; Lal, 1998.). The most prudent course is to continue to recycle most crop residues back into the soil, where they are vital in keeping organic matter levels high enough to make the soil more open to air and water, more resistant to soil erosion, and more productive .Intensive agriculture of the last 5 to 6 decades has already removed 20 to $50 \%$ of the original soil carbon, and some areas have lost $70 \%$. To maintain soil $\mathrm{C}$ levels, no crop residues should be removed under any tillage systems or on highly erodible lands (Johnson, 2006 ; Magdoff and Weil, 2004; Lal,1998).

Furthermore, producing biofuels like ethanol in sugarcane is accompanied by the generation of huge liquid wastes called distillery slops. Corn ethanol plants generate $13 \mathrm{~L}$ of wastewater for every L of ethanol produced (Pimentel and Patzek, 2005). While ethanol contains considerable amount of potash and many other nutrients and has fertilizer value, it is highly acidic, is high in biological oxygen demand (BOD), chemical oxygen demand (COD), and is foul-smelling. It is a highly pollutive waste if not properly treated and disposed. The production target of 120 billion $\mathrm{L}$ of ethanol and about 12 billion L of biodiesel by 2030 
will produce about 3 trillion L of liquid wastes (Mendoza et al., 2007; Demafelis, 2007). Where will all these liquid wastes be thrown out? Avid proponents of biofuel will argue that the liquid wastes could be treated for re-use. The treatment costs will be enormous, will increase health costs, kill fish with insecticides that work their way up the food chain (Troeh, 2005).

\section{Biofuels and food prices}

Production of biofuels consumed almost $100 \mathrm{M}$ tons of grains in 2007. It is hard to defend biofuels as not directly causing the current world food price spikes. This year, the estimated deficit was $53 \mathrm{M}$ tons (16April, 2008 Monbiot.com). It is clear that without biofuel in the food equation, there is still enough food supply. If fermenting corn will be stopped, its price will decrease by 20 to $30 \%$. It is now certain that Biofuels have forced global food prices up by $75 \%$ (Chakrabortty, 2008). In the US, ethanol production from corn (2008) is estimated at 11.4 billion gallons . This is equivalent to the food caloric requirements of $450 \mathrm{M}$ people (at $3000 \mathrm{Kcal} /$ person ). By 2017, about 35 billion gallons will be produced which translates to the food caloric requirements of $1.4 \mathrm{~B}$ people (Mendoza, 2008). We cannot dictate to the US what to do with their corn. But the US produces $40 \%$ of the world's total corn and supplies $70 \%$ of all corn exports. Their ethanol production from corn not only propelled the increase in corn price but also in all food commodities including meat and dairy. Corn constitutes $50 \%$ or more of livestock feed (Carter \& Miller,2007).

There are about 2.7 billion people in the world who are living on the equivalent of less than $\$ 2$ a day (World Bank, 2001) and $85 \%$ of Filipinos live on less than $\$ 2$ a day! (CIA, 2006). Food crisis happens in many poor and food-deficient countries and it is true even in rich countries: 37 million poor in the U.S (observer.guardian.co.uk); 80 million in China (Paromita Shastri, livemint.com); 37 million poor in Indonesia (Indonesia-pretoria.org.za); 24 million in the Philippines (ifad.org) and 
250 million in India (ews.bbc.co.uk). Caloric consumption typically declines as price rises by a ratio of $1: 2$ or for every $1 \%$ rise in the food price, 16 million people are made food-insecure. Some 1.2 billion people could be chronically hungry by $2025-600$ million more than previously predicted (Runge and Sennauer, 2007 ). It is in this context that the a biofuel production should be delayed (Harrabin, 2008)

\section{What renowned people \& institutions say about biofuels}

"Biofuels policy in the EU and the UK may have run ahead of the science". Professor Robert Watson Jacques Diouf, head of the UN Food and Agriculture Organization said that "a very serious risk that fewer people will be able to get food," particularly in the developing world, http://www.iht.com/articles/2007/12/17/europe/food.php .

The International Monetary Fund noted that " The use of food as source of fuel may have serious implications on the supply of food if the expansion of biofuels continues." "The stomachs of the poor are losing out to the cars of the wealthy."

Jean Zeigler, a UN special rapporteur, calls the biofuel trade "a crime against humanity."

"Biofuels could end up damaging the natural world rather than saving it from global warming", Jeffrey A McNeely, chief scientist of IUCN .

We must avoid falling into the trap of having a "cure worse than the disease!", the biofuel malady, according to Dr. Paul Crutzen.

\section{Do we have options other than biofuels?}

For the Philippines, there are many options in pursuing energy security other than biofuels and they are as follows : improve energy use efficiency -minimize the use of cars - walk, bike ride, shift to more renewable and environment-friendly sources of energy- solar, wave, and wind energy (Mendoza, 2007; Rodolfo, 2008 ).

The food crisis is a wake-up call. There are several OPTIONS that can be done both on the production and consumption side.

On the food supply or food production, there are many possibilities 
(Mendoza, 2008): 1) Growing food the whole year round is possible where sunlight is available. All the rest can be provided (soil, composts, water). If one so desires, land availability is not the issue. It is the willingness and interest of the individual. Sustainable food advocates claim that family farms and gardens not only can feed the world, they are the only food production approach that can sustain food in the long run (Pretty,1996; Jeavons, 2001). A sunshine-rich country like the Philippines, whose climate is so accommodating for the whole year round growth of crops provided water is available, need not fear hunger (Mendoza,2008). We have no freezing winter that requires expensive heated glasshouses to grow crops.

Oil-based agriculture is unsustainable agriculture (Mae-Wan Ho, 2008). This old paradigm of industrial, energy-intensive, and toxic agriculture is a concept of the past (IAASTD, 2008). Small-scale farming and agro-ecological methods provide the way forward to avert the current food crisis and meet the needs of local communities. For the first time an independent, global assessment had acknowledged that farming has a diversity of environmental and social functions and that nations and peoples have the right to democratically determine their best food and agricultural policies (http://www.agassessment-watch.organdhttp:// www.panna.org/).

There is a need to pursue a biodiverse, integrated, and organic/ sustainable (BIOS) agriculture as the core strategy to sustainable food security (Mendoza,2008). Organic agriculture can feed the world (Pretty, 1996; Leu, 2007; Badgley et al., 2007 ; Scialabba and Hattam, 2002 ). Organic farming requires lesser energy in growing crops (Niggli et al., 2009) and it is consistent with the declining fossil fuel oil supply; and diversified and integrated farming gives higher production compared with the conventional monocrop farming (Stanhill, 1990; Pimentel et al., 2005; Pretty, 2001, 2003). A case study comparing a monocrop and a diverse farm showed that the estimated food caloric value produced in the diverse farm is $61.7 \%$ higher than the conventional monocrop rice farm (Mendoza, 2001). Sufficient food calories (65\% of $2000 \mathrm{kcal} /$ day) for 48 persons in one year could be harvested in this farm.

BIO-farm has 2 important equirements, namely : 1) bio-farming is 
decision-intensive, hence, the farmers should own the land to enable them to make independent decisions and motivate them to rebuild and restore soil fertility@ impoverished soil $>>>$ low yield $>>>$ impoverished farmers $>>>$ malnourished farm families ...... Smaller, more diverse farming systems require a level of husbandry. Organic crops and livestock demand specialist knowledge and regular monitoring(http:// www.theecologist.org/archive_detail.asp?content_id=1184).

2) The farmers need seed support as they have lost their indigenous/ traditional seeds through long years of monoculture farming practices. The UN FAO estimates that 75 per cent of the genetic diversity of agricultural crops has been lost over the past 100 years (FAO, 1997).

On the consumption or demand side, the changing climatic pattern and the diminishing resource requirements to grow sufficient rice call for a change in the thinking that if we have not eaten rice, our meal is not complete or we have not eaten yet. Three options were earlier forwarded (Mendoza, 2008):

Option 1. Diversify our food caloric sources. We can supplement rice with corn, camote, or any other carbohydrate yielding crops. Simple estimates show that reducing the $65 \%$ caloric energy supplied by rice (translates to $124 \mathrm{~kg} /$ capita) to only $50 \%$ (translates to $95 \mathrm{~kg} /$ capita) makes us immediately self-sufficient in rice.

Option 2. Food wastage must be minimized or avoided. The current world food shortage is not simply the result of a production shortfall. It is how the food we produced are utilized or wasted. Why do we need to polish rice? Unpolished rice is more nutritious (rich in vitamins), and it gives higher milling recovery (from $64 \%$ to $72 \%$ milling recovery of unpolished rice; bran is about $8 \%$ ). This translates to about $1.2 \mathrm{M}$ tons of rice savings. About 10 to $15 \%$ more rice will be saved if we eat unpolished rice since we can not eat the same amount of rice compared to wellpolished rice . Add together, this sums up to about 2.4 million tons of rice. We become more than self-sufficient in rice.

Option 3. In the Philippines, about 7.0 million tons of corn are fed to our poultry and livestock (We produce 6.0 tons, we import the rests). We just divert 2.5 million tons of corn, mill them and mix the milled 
corn grains with rice at 10 to $15 \%$, we automatically become food caloric self- sufficient. In the developed world, particularly the US, about $2 / 3$ of their small grains (cereals of soybean) are fed to livestock. Many people in the world want to adopt the American diet. To eat like the average Americans, we would need 5 more Earths, or only about 1 billion would live if all people eat like the Americans. Of the 2.13 B tons of grains produced this year, only $1.01 \mathrm{~B}$ ton, according to the United Nation's Food and Agriculture Organization, will be directly consumed by the people. The production of biofuels will consume almost $100 \mathrm{M}$ tonnes (16April, 2008Monbiot.com) to fuel cars, but $760 \mathrm{M}$ tons will be fed to animals - an amount equivalent to 14 times the global food deficit of 56 Mtons (FAO, 2006)

The growing affluence of China and India leads to booming meat consumption, and is now the single dominant factor pushing up food and energy usage. As the Chinese become more affluent, they can now afford to buy more meat, beef and chevon. They now raise billions of sheep, and grow lots of corn and soybean just to feed their livestock $\{(1 \mathrm{~kg}$ pork $=5.6 \mathrm{~kg}$ corn equivalent, $1 \mathrm{~kg}$ broiler chicken $=4.8 \mathrm{~kg}$ corn equivalent, $1 \mathrm{~kg}$ corn equivalent $=0.7 \mathrm{~kg}$ corn $+0.3 \mathrm{~kg}$ soybean, $1 \mathrm{~kg}$ soybean $=3.2$ $\mathrm{kg}$ corn) (Mendoza, 2001). This is called the thermodynamic loss of food via food type conversion. This is called the thermodynamic loss of food via food type conversion. As feed, grain $\rightarrow$ animals $\rightarrow$ man, we lose $90 \%$ protein, $96 \%$ calories, $99 \%$ carbohydrates, $100 \%$ fiber. The 50 gram meat-dietary intake per day translates to 2 days of food if eaten as corn or soybean. It is a choice then of eating meat today and forgoing food for 2 days. It is not that we should abandon eating meat. Furthermore, the livestock sector is a major player, responsible for $18 \%$ of green house gas emissions in $\mathrm{C}_{2}$ equivalent (Steinfeld et al., 2006). The logic is to raise animals but not feeding them food that directly competes with human food. The ruminants feed on grasses or fibrous crop residues, in turn, producing manure for composts to fertilize our crops. For the Philippines, we are simply lucky as we are endowed with large coastal and marine waters (220 M ha) and fresh water (1.0 M ha) where fish can 
grow and multiply for the protein part of our nutrition. But again, good governance and people's cooperation in protecting the sea (preserve the remaining mangroves and plant more as they serve as fish breeding grounds) is the key to the revival of our seas teeming with fish. Bringing back the watersheds that supply free-flowing fresh water to the river during summer months favors the breeding and fingerling production of many fish species in the resulting brackish water of river banks.

\section{SUMMARY AND CONCLUSIONS}

Achieving food security and producing biofuel to power cars are challenges humanity faces in the new millennium. Food reserves in storage are claimed to have declined by $22 \%$ compared to the 2005 2006 level and that food reserves shall decline further this year 2008. In the Philippines, rice is the barometer of food security. The government claims there is no rice shortage. At present, the price of rice is again low if the cost of production is to be considered. By 2015, or even earlier, rice supply will become even more precarious since a $22 \%$ supply deficit should be anticipated if the rice output of this year (2008)is simply maintained. It is hard selling that there is no rice crisis and that there is simply a price crisis. The price of rice relative to the 2007 level has increased by $2.22 \times$ (P17.50 to P40.0/kg, June 2008 ). Many believed that the current price of rice is already high. Using 3 different procedures in determining the true price of rice showed that $1 \mathrm{~kg}$ of rice is worth P66/kg (at \$1136/ton import price), P68.4/kg relative to its price in 1975 (CPI) and it is $\mathrm{P} 86 / \mathrm{kg}$ (considering price parity with the price of oil, oil-based inputs and just labor).

The world, in general, and the Philippines, in particular, is already experiencing difficulties in producing sufficient food for the growing population. Producing renewable energy through biofuel to address the declining oil supply, requires the same resources or inputs (land, water, initial energy or oil, fertilizer and machineries). In terms of land, as early as the 1980s, all the prime lands in the world were already used for agriand - aquaculture(1970s for the Philippines ). Of the 1.4B ha of cultivated lands, $30 \%$ are already degraded. Erosion is occurring at $9 \mathrm{M}$ ha per year 
and soils are being destroyed at a rate $13 x$ faster than they are being formed. If biofuels are to be produced at the intended amount, they will be grown in some $564 \mathrm{M}$ ha more, the additional land area needed to produce the food requirements of 2 billion people by 2030 .

So much land shall be used to produce biofuel in response to the oil crisis. The US government study conducted showed that all forms of renewable energy, including biofuels, however, will only supply $9 \%$ of energy needs or $2.25 \%$ if only the 4 (biofuel, solar, wind and wave) renewable energy sources are considered. If all the corn and soybean in the US will be processed, they will supply only 12 and $6 \%$ of their gasoline and diesel requirements, respectively. In the Philippines, fermenting all the sugarcane harvested in 390,000 ha sugar lands will only satisfy $7.5 \%$ of our gasoline requirement by 2011. Sugarcane will have to be planted in 5.3 $\mathrm{M}$ ha to produce enough ethanol. This is the same area needed for food crops to supply the additional food requirements of 15-20 million Filipinos by 2020. Aside from sugarcane, there are other crops being considered in producing bioethanol in the Philippines. Sweet sorghum is one. It should be pointed out that sweet sorghum will be planted in lands using water which otherwise will be used for food crops. Jatropha, on the other hand, is being promoted as a biodiesel crop option since the food and many other uses of coconut oil have already made its price prohibitive. The main drawback of Jatropha is its low seed/oil yield, thus, making its production uneconomical and low in energy balance. More detailed studies should be done.

Producing biofuels also requires more water (up to 10,000 L of water/ li) than producing $1 \mathrm{~kg}$ of corn or rice $(5000 \mathrm{~L}$ of water $/ \mathrm{kg})$ for food. The world is already suffering from varying levels of water scarcity. At present, $74 \%$ of water is used to irrigate food crops. Biofuel crops, at the current area planted, use only $1 \%$ water but this water consumption will increase to $80 \%$ if the biofuel production plan materializes. Current data show that one out of three individuals in the world is now suffering from water scarcity. Global warming/ global climate change, droughts, more forest fires and high evaporation triggered by high temperature will further magnify the diminishing supply of fresh water both for agriculture and domestic use (household and industries). 
The effect of biofuels on the environment and on biodiversity is another concern. Biofuel production produces voluminous wastes. Where will all the liquid wastes be thrown? Bio-cleaning the wastes is so cashand energy-intensive, nullifying the energy balance or net energy yield of biofuel. Biofuel crops planted in new lands necessitates land clearing using fire as the easiest, cheapest and fastest tool. Part of the low energy return from biofuel production is that it also burns oil to prepare lands, plant, fertilize, harvest, and haul the feedstocks, thus, burning a tremendous amount of oil. Ethanol return from corn is only $6 \%$. Furthermore, Nitrogen Oxide (NOx) emission from biofuel production increases due to the use of fertilizer and due to the burning of biomass and oil. Biofuel feedstock establishment is facilitated by burning and production thrives on monoculture. Endemic species' habitats are destroyed and biodiversity is sacrificed. This also happened when humankind burned and cultivated lands for food crops. The simple linear thought, therefore, is.....more crops for food or biofuel = more lands and water use $=$ more fertilizer or oil use $=$ more erosion $=$ more greenhouse gas emission.

Humankind is in a difficult bind. Indeed, how could we face the millennium challenge of simultaneous food and biofuel production without sacrificing food security? Biofuel production is currently propelling further food price spikes. About 3 billion people are now affected especially those who spend $60-70 \%$ of their income on food, as they are simply priced out. The stomach of the poor are emptied by the biofuel-powered cars of the rich. Many Filipinos are hungrier and feel poorer than ever. The Millenium Development Goal of poverty reduction is set back once again.

\section{ACKNOWLEDGMENT}

The author acknowledges, with thanks, National Scientist and Academician Dr. Ricardo Lantican who initially reviewed and provided inputs on the paper and the 2 international reviewers for their suggestions to improve it further and other colleagues in the Crop Science cluster, College of Agriculture, UP los Banos, Laguna. 


\section{LITERATURE CITED}

ALISTER, D. 2006. http://today.reuters.com/News/CrisesArticle.aspx?storyId $=\mathrm{L} 188507258 / 24 / 2006$

ALTIERI, M and E. BRAVO. 2007. "The ecological and social tragedy of biofuels," 5/ 1/07, www.foodfirst.org

ANDREWS, S. Feb 22, 2006. Crop Residue Removal for Biomass Energy Production: Effects on Soils and Recommendations. USDA-Natural Resource Conservation Service.

http://culturechange.org/cms - Culture Change Powered by Mambo Generated: 14 April, $2007,22: 15$

ASSOCIATED PRESS. "Research shows ethanol isn't worth the energy". 17 July 2005. http://www.msnbc.msn.com/id/8607389/

BP GLOBAL STATISTICAL REVIEW OF WORLD ENERGY. June 2007. http:// www.bp.com/statisticalreview

BADGELY, C., J. MOGHTADER., E. QUINTERO, E. ZAHEM, M. J. CHAPPEL, K. AVILES-VASQUEZ, A. SAMULON and PERFECTO, I. 2006. Organic agriculture and the global food supply. Renewable Agric and Food Systems 22(2):86-108.

BLANCO-CANQUI, H. et al. 2006. Rapid Changes in Soil Carbon and structural properties due to stover removal from no-till corn plots. Soil Science 171(6): 468-482.

BRADLEY, FERN MARSHALL AND BARBARA W. ELLIS, (eds.) 1993. Rodale's All-New Encyclopedia of Organic Gardening: The indispensable resource for every gardener. Rodale Books.

BRAR, D. S. and G. S. KHUSH. 1997. Wide hybridization for rice improvements: Alien gene transfer and molecular characterization of introgression. In: Interspecific hybridization: Progress and prospect.M. P. Jones, M. Dingkhun, D. E. Johnson and Fagade S.O. 1992. eds.WARDA, 01BP2551, Bouake, Cote d' voire.dening. Emmaus, Pennyslvania: Rodale.pp.21-29

BURINGH, P. 1989. Availability of agricultural land for crop and livestock production. In: Food and Natural Resources. D. Pimentel and C.W. Hall. eds. 69-83. San Diego: Academic Press

BADGLEY et al .2007.Organic agriculture and the global food supply. Renewable Agriculture and Food Systems 22(2); 86-108. 
CARTER, C. A. and H. I. MILLER, "Hidden costs of corn based ethanol". Christian Science Monitor, 21 May 2007. http://www.csmonitor.com/2007/0521/p09s02coop.html

CIA. 2006. Philippines. World Factbook. 11 July 2006, Accessed 27 September 2006. http://sportsforum.ws/sd/factbook/geos/rp.html\#Econ. Caroline Lucas Mep, et $a l$ "Fuelling a Food Crisis: The impact of peak oil on food security", The Greens/ European Free Alliance, European Parliament, 12/06

CHAKRABORTTY, A. 2008.Secret Report: Biofuel Caused Food Crisis. http:// www.guardian.co.uk/environment $/ 2008 / \mathrm{jul} / 03 /$ biofuels.renewableenergy Guardian.0704 031

CLEVELAND, C., J.ROBERT, K. KAUFMANN and DAVID I. STERN . 1999. Aggregation and the role of energy in the economy. Center for Energy and Environmental Studies and Department of Geography. Boston University, Centre for Resource and Environmental Studies. Australian National University, Canberra, 1999)

COHEN, JE. 1995. How Many People Can The Earth Support? New York, W.W. Norton \& Company, Inc.

COX, T.S., M. BENDER, C. PICONE, D. L. VAN TASSEL, J. B. HOLLAND, C. E. BRUMMER, B. E. ZOELLER, A. H. PATERSON, and W. JACKSON. 2002. Breeding perennial grain crops. Critical Reviews in Plant Sciences 21: 59-91.

COX T.S., J. G. GLOVER, D. L. VAN TASSEL, C. M. COX and L. R. DEHANN. 2006. Prospects for developing perennial grain crops. BioScience 56: 649-59.

COX, S. 2008 . Ending 10,000 Years of Conflict between Agriculture and Nature.http:/ /www.i-sis.org.uk/full/Ending10000YearsOfConflictFull.php ISIS Press Release $26 / 06 / 08$

DEFRA. 2005. The Validity of Food Miles as an Indicator of Sustainable Development: Final Report. Department of Environment Food and Rural Affairs.

DEMAFELIS, R.B.2008.Towards a Village-scale biodiesel processing of Jatropha curcas in the Philippines. The Phil. J of Crop Science 33(1): 59-68.

DOIRON. 2008. http://www.alternet.org/story/81769/

DOYLE, A. 2007. Food, biofuels could worsen water shortages. http:// today.reuters.com/News/CrisesArticle.aspx?storyId $=\mathrm{L} 18850725$

DUFEY, A. 2006. International trade in biofuels: Good for development? and good for environment? International Institute for Environment and Development. 
DELFT HYDRAULICS IN GEORGE MONBIOT. If we want to save the planet, we need a five-year freeze on biofuels. The Guardian, 3/27/2007

EIA. 2000. US-EIA Presentation : Long Term World Oil Supply, (http:// www.eia.doe.gov/pub/oil_gas/petroleum/presentations/2000/ long_term_supplyindex.htm)

FAO (1997). The State of the Worlds Plant Genetic Resources for Food and Agriculture. Food Agriculture Organisation of the United Nations, Rome.

FAO. 2006. Livestock's Long Shadow. ftp://ftp.fao.org/docrep/fao/010/a0701e/ a0701e.pdf

FAO.2008.Crop Prospects and Food Situation . http://www.fao.org/docrep/010/ai465e/ ai465e $01 . h t m$

FARRELL, A. E., R. J. PLEVIN, B. T. TURNER, A. D. JONES, M. O'HARE, and D. M. KAMMEN. Ethanol can contribute to energy and environmental goals. Science, Vol. 311, p. 506-508. http://rael.berkeley.edu/ebamm/ FarrellEthanolScience012706.pdf

FARRELL et al. 2006. Ethanol Can Contribute to Energy and Environmental Goals. Science 311: 506-508

FORD, R. and B. SENAUER. How Biofuels Could Starve the Poor. Foreign Affairs, May/June 2007

GLENNON, R. 2002. Water Follies. Groundwater Pumping and the Fate of America's Fresh Waters. Island Press

GOODCHILD, P. 2007. petergoodchild@interhop.net

HAMER, E. and M. ANSLOW. 2008. 10 reasons why organic can feed the world. http://www.theecologist.org/archive_detail.asp?content_id=1184

HANSEN, J .2003. Twenty Years Later: Tipping Points Near on Global Warming http://www.huffingtonpost.com/dr-james-hansen/twenty-years-latertippin_b_108766.html .

HILL, J., et al.,. 2006."Environmental, Economic, and Energetic Costs and Benefits of Biodiesel and Ethanol Biofuels," Proceedings of the National Academy of Sciences 103: 11206-10.

HALL, C. et al. 2003. Hydrocarbons and the Evolution of Human Culture. Nature 426: $318-22$

HAMER, E. and M. ANSLOW. 2008. 10 reasons why organic can feed the world. http://www.theecologist.org/archive_detail.asp?content_id=1184 
HARRABIN, R. 2008. Call for delay to biofuels policy .BBC Environment Analyst http://news.bbc.co.uk/2/hi/science/nature/7309099.stm

HELLER, M.C. and G. A. KEOLEIAN. 2003. Assessing the sustainability of the US food system: a life cycle perspective. Agricultural Systems 76:1007-1041

HOLT-GIMÉNEZ, E.2007. Exploding the Biofuel Myths Food First/Institute for Food and Development Policy (http://www.foodfirst.org/, published in http:// www.foodfirst.org/node/1715>

IAASTD.2008. (http://www.agassessment-watch.organdhttp://www.panna.org/).

JEAVONS, J. 2001. Biointensive Sustainable Mini-Farming: I. The Challenge. Journal of Sustainable Agriculture 19(2):49-63

JOHNSON JD et al. 2006. A matter of balance: Conservation \& renewable energy. Journal of Soil and Water Conservation 61:120A-125A

JOHNSON, R. N. and G. D. LIBECAP. Information distortion and competitive remedies in government transfer programs: The case of ethanol, Economics of Governance, 001, vol. 2 p. 101-134.economics.eller.arizona.edu/downloads/working_papers/ ethanEconGovIIs.pdf. 135.

JORDAN N, G. BOODY, W. BROUSSARD, J. D. GLOVER, D. KEENEY, B. H. MCCOWN, G. McISAAC, M. MULLER, H. MURRAY, J. NEAL, C. PANSING, R. E. TURNER, K. WARNER, and D.WYSE. 2007. Sustainable development of the agricultural bio-economy. Science 316:1570-

KINDELL, H. H. and D. PIMENTEL.1994 Constraints on the Expansion of Global Food Supply, Ambio Vol. 23 No. 3, May 1994. The Royal Swedish Academy of Sciences. http://www.dieoff.com/page $36 \mathrm{htm}$

LANG, S. S. 2005.Cornell ecologist's study finds that producing ethanol and biodiesel from corn and other crops is not worth the energy. Cornell University News Service, 5 July 2005. news.cornell.edu/stories/July05/ethanol.toocostly.ssl.html

LEU, A. 2007. Organic Agriculture Can Feed the World in Organic Farming. Winter 2007, citing Jules

MAE-WAN HO. 2008. Organic Cuba without Fossil Fuels. http://www.i- sis.org.uk/ full/OrganicCubawithoutFossilFuelsFull.php. SIS Press Release 21/01/08

MACEDO, I.C., M.R. LIMA VERDE LEAL and J.E.A. RAMOS DA SILVA. 2004. Assessment of greenhouse gas emissions in the production and use offuel ethanol in Brazil. Government of the State of Sao Paulo, Brazil, $36 \mathrm{p}$.

MAGDOFF, F. and R. R. WEIL. 2004. Soil Organic Matter in Sustainable Agric.CRC Press LLC 398 p. 
MAGDOFF, F.2008.The Political Economy and Ecology of Biofuels. http:// www.monthlyreview.org/080714magdoff.php (Accessed 8 sept 2008)

MCLAUGHLIN, N.B., et al.2000. Comparison of energy inputs for inorganic fertilizer and manure based corn production .Canadian Agricultural Engineering 42(1)

MENDOZA, T. C. 2001. Pursuing Debates in Food Security in the New Millenium. SEARCA Professorial Chair lecture. Dept. of Agronomy, College of Agriculture, UP Los Banos, Phil. June 2001

MENDOZA, T. C. 2007. The Energetics of Ethanol Production and its Implications. Asia Life Sciences 16(2):115-138.

MENDOZA,. T. C.2007.Are biofuels really beneficial for humanity? Philippine Journal of Crop Science (PJCS) 32(3): 83-98.

MENDOZA, T.C. 2008. Agronomic features, Ethanol Yields, Resource Use of Four Feedstocks for Ethanol Production Under Phil. Condition. The Phil. J of Crop Science 3(1): 21-36.

MENDOZA, T.C., E.T. CASTILLO and R. DEMAFILIS. 2007. The Costs of Ethanol Production from Sugarcane under Eastern Batangas Conditions. The Phil. J of Crop Science 32(3):25-48

MENDOZA, T.C. 2008. Why food prices increase \& what can be done. The Phil. Journal of Crop Science 33(2): 87-101

RATILlA, B. and T. C. MENDOZA. 2008. The Energetics of Biodiesel Production from Jatropha. Special paper in Agr 291(Energetics of Crop Agriculture) April 8, 2008. Crop science cluster, College of agriculture, UP Los Banos, Laguna

MCKEI, R. (2008). How the myth of food miles hurts the planet. Retrieved March 23, 2008, from http://www.guardian.co.uk/environment/2008/mar/23/ food.ethicalliving

NIGGLI, U., A. FLIEßBACH, P. HEPPERLY, and N. SCIALABBA. 2009. Low Greenhouse Gas Agriculture: Mitigation and Adaptation Potential of Sustainable Farming Systems. FAO, April 2009, Rev. 2 - 2009.

OFON, A. 2008. Globe and Mail, Canada. http://www.theglobeandmail.com/servlet/ story/RTGAM.20080410.wfood0411/BNStory/International/home

OLMSTEAD, J. 2006. What About the Land? A look at the impacts of biofuels production, in the U.S. and the world. Grist Pfeiffer, DA. 2003. EatingFossilFuels .http://www.fromthewilderness.com/free/ww3/100303_eating_oil.html/or http:/ /www.mountainsentinel.com/content/eatingfossilfuels.pdf

PIMENTEL, D. and M. GIAMPIETRO. 1994. Food, Land, Population and the U.S. Economy, Carrying Capacity Network. 11/21/1994. http://www.dieoff.com/ 
page 55.htm

PIMENTEL, D., C. HARVEY, P. RESOSUDARMO, K. SINCLAIR, D. KURZ, M. MCNAIR, S. CRIST, L. SHPRITZ, L. FITTON, R. SAFFOURI, and R. BLAIR. 1995. Environmental and economic cost of soil erosion and conservation benefits. Science 267:1117-1123.

PIMENTEL, D., P. HEPPERLY, J. HANSON, D. DOUDS, and R. SEIDEL. 2005. Environmental, energetic and economic comparisons of organic and conventional farming systems. BioScience 55:573-582.

PIMENTEL, D. and T. W. PATZEK. Ethanol production using corn, switchgrass, and wood; biodiesel production using soybean and sunflower. Natural Resources Research, v. 14, No. 1, March 2005, p. 65-76. h t t p : / / petroleum.berkeley.edu/papers/Biofuels/NRRethanol.2005.pdf.

PRETTY, J. 2006. http://www.rimisp.org/getdoc.php?docid=6440 Pretty, 1999, The Living Land.

PRETTY J. 1996. Could sustainable agriculture feed the world? Biologist 43:130-133.

PRETTY, J. and R. HINE. 2001. Reducing food poverty with sustainable agriculture: A summary of new evidence. Final Report from the 'SAFE World' Research Project, University of Essex. Available at Web site: http://www2.essex.ac.uk/ ces/ResearchProgrammes/SAFEWexecsummfinalreport.htm

PRETTY, J.N., J. I. L. MORISON, and R. E. HINE. 2003. Reducing food poverty by increasing agricultural sustainability in developing countries. Agriculture, Ecosystems and Environment 95:217-234.

WIDENOJA, R. and B. HALWEIL .2008. Analysis: Banning "Bad" Biofuels, Becoming Better Consumers. http://www.worldwatch.org/node/5587- January 23, 2008 12:05am

ROSENTHAL, E. http://www.iht.com/articles/2007/12/17/europe/food.php)

RODOLFO,K. 2008. "Peak Oil": The Global Crisis of Diminishing Petroleum Supply, and Its Implications for the Philippines. Asian Studies Journal 41(1):41-101

STANHILL, G. 1990. The comparative productivity of organic agriculture. Agriculture Ecosystems And Environment 30:1-26

SIMBERLOFF, D, and SWACKHAMER, D. 2001. Forecasting agriculturally driven global environmental change. Science 292: 281-4.

TEGTMEIER, E., et al. 2004. External Costs of Agricultural Production in the United States. International Journal of AgriculturalSustainability 2/1 
TILMAN, D., J. FARGIONE, B. WOLFF, C. D'ANTONIO, A. DOBSON, R. HOWARTH, D. SCHINDLER, W. H. SCHLESINGER, F. TROEH. et al. 2005. Soils and Soil Fertility. 6th edition. Blackwell Publishing. $315 \mathrm{p}$

UNPF (United Nations Population Fund). World Population to 2300. New York, United Nations. http://www.unfpa.org/swp/ US EPA, 1998, Ruminant Livestock and the Global Environment

VIDAL, J. 2007. Global Food Crisis Looms as Climate Change and Fuel Shortages Bite. The Guardian. Nov. 3, 2007 http://www.guardian.co.uk/environment/2007/ nov/03/food.climatechange

VITOUSEK, P.M. et al. 1986. Bioscience 36. http://www.science.duq.edu/esm/unit23

YACOBUCCI, B. 2006. Fuel Ethanol: Background and Public Policy Issues. CRS Report for Congress. International Energy Agency, 'World Energy Outlook 2006,' Paris 2006

SCIALABBA, N.EL-H. and C. HATTAM. (eds). 2002. Organic Agriculture, Environment, and Food Security. Food and Agriculture Organization of the United Nations, Rome, Italy.

ZIEGLER, J. 2008. Ziegler: Biofuel is a crime against humanity. France 24, April 14, 2008. france24.com

VITOUSEK, P.M., et al. 1986. Human appropriation of the products of photosynthesis. Bioscience 36, http://www.science.duq.edu/esm/unit2-3 